\title{
Biomass and primary productivity of an Alnus viridis stand - a case study from the Schächental valley, Switzerland
}

\section{Eric Wiedmer ${ }^{1}$ and Béatrice Senn-Irlet ${ }^{2}$}

1 Institut für Pflanzenwissenschaften der Universität Bern, Altenbergrain 21, CH-3013 Bern

2 Eidgenössische Forschungsanstalt für Wald, Schnee und Landschaft WSL, Zürcherstrasse 111,CH-8903 Birmensdorf; e-mail: beatrice.senn@wsl.ch

Manuscript accepted 6 March 2006

\begin{abstract}
Wiedmer E. and Senn-Irlet B. 2006. Biomass and primary productivity of an Alnus viridis stand - a case study from the Schächental valley, Switzerland. Bot. Helv. 116: 55-64.

Green alder (Alnus viridis) stands are spreading rapidly in the subalpine belt of the Swiss Alps. To understand this rapid colonisation, estimates of above ground biomass and net primary productivity were made in an old-growth pure stand of Alnus viridis in central Switzerland. A total above-ground biomass of $89.3 \mathrm{t} \mathrm{ha}^{-1}$ was recorded, to which Alnus viridis contributed $97.8 \%$ and the understorey vegetation $2.2 \%$. The annual above-ground production of $A$. viridis was estimated to be $6.18 \mathrm{t}$ ha- $1 \mathrm{yr}^{-1}$, of which $61.5 \%$ were allocated to leaf production, $21.7 \%$ to stem (i.e. caudex) growth and $16.8 \%$ to increment of branch-wood. The above ground biomass and the annual production of A. viridis are high when compared with other subarctic or subalpine scrub-woodlands. This might be due to its high stem density, which is produced through clonal growth.
\end{abstract}

Key words: Green alder, non-destructive biomass sampling, primary production, subalpine vegetation.

\section{Introduction}

Green alder (Alnus viridis (Chaix.) DC.) is an early successional shrub that invades screes, avalanche slide paths and pastures in the subalpine zone of the Alpine, Carpathian and Dinaric chains in Europe. In the Western Alps, green alder stands (Alnetum viridis Br.-B1.) are widely spread at an altitude of 1000-2000 m. a.s.l., mostly on moist, north-exposed slopes on silicious bedrock (Wettstein 2001). At this altitude, Richard (1967) found 16\% of the surface of the Mt. Blanc region colonised by green alder. 
An expansion of this vegetation type due to deforestation and extensive grazing (Rubli 1976) has been observed in the last decades in the Western Alps (Barbero et al. 1991; Wettstein 1999; Anthelme et al. 2002). A study in the Urserental valley revealed a surface colonised by green alder that has increased by $32 \%$ since $1965\left(8.5 \mathrm{ha} \mathrm{yr}^{-1}\right)$ and covering 23\% (999 ha) of the valley in 1994 (Wettstein 1999). Moreover, green alder was often found in atypical places such as pastures with southern exposure. This trend of increasing scrub vegetation, though less pronounced than in the Urserental has been confirmed for the whole subalpine belt of the Swiss Alps. The Swiss national forest inventory noted for the region of the Swiss Alps an increase of shrub woodland by $17.9 \%$ in the period between $1983 / 85$ and $1993 / 95$ with almost $66 \%$ of it consisting of Alnus viridis (Brassel and Brändli 1999).

Currently the Alnetum viridis is probably the most rapidly spreading vegetation type in Switzerland, colonising mainly abandoned subalpine pastures. This expansion brings major modifications in the functioning of these ecosystems. Plant diversity may be threatened and the dense stands may inhibit or retard the establishment of late successional arboreal coniferous species (Anthelme et al. 2002, 2003). To understand the dynamics of this rapid colonisation we have to understand the biomass allocation and biomass turnover of Alnus viridis. However, only few data on biomass are available, and productivity estimations are lacking so far. This is probably due to the use of Alnus viridis being restricted to soil bioengineering (Graf et al. 2003) and the low economic value of the timber.

The aim of the case study is to characterise the above ground biomass of an oldgrowth Alnetum viridis and to give an estimation of the productivity of the stand. To this purpose the site of Steinboden, Schächental valley, Switzerland, was selected, based on the results of a survey of 33 green alder stands in central Switzerland (Mürner 1998) because of its characteristic and homogenous species composition.

\section{Materials and methods}

\section{Site description}

The study was carried out at the site Steinboden above Unterschächen, Kanton Uri, Switzerland. At this site, green alder scrub-wood is best developed on a moist, northexposed slope with an inclination of $30^{\circ}$ at an altitude of $1500-2000 \mathrm{~m}$ a.s.l. The bedrock material is an acidic sandstone (Taveyannaz sandstone). The climatic conditions of the site meet the requirements of Alnus viridis as described by Richard (1968), with a high annual precipitation of 2000-2400 mm, a low July mean temperature of $12-15{ }^{\circ} \mathrm{C}$, and with snow protecting the scrubs from mid November to April/May.

A uniform part of the stand was chosen for the study at an altitude of $1630 \mathrm{~m}$ a.s.l. In this part, Alnus viridis is the only tree species, although a few Acer pseudoplatanus L., Sorbus aucuparia L. and some small crippled Picea abies L. grow nearby.

\section{Morphology of Alnus viridis}

Alnus viridis forms stocks from which several trunks sprout. Due to the snow cover, the trunks are bent towards the ground, take root and produce new stocks with adventitious shoots. This type of clonal growth leads to the formation of dense stands, in which it is impossible to recognise individual plants by simple visual inspection. The more or less hidden horizontal stems have been called "caudices" by Elkington and Jones (1974). In the present study, an "individual" or "tree" was defined as one caudex 
and all branches sprouting from it. A caudex was defined as the woody stem from the point at which it emerged from the soil-litter layer to the ramification at which the diameter of the main branch was less than $2 \mathrm{~cm}$. The remaining apical part of the main branch was treated as a side branch.

\section{Biomass measurements of Alnus viridis}

The above-ground biomass of Alnus viridis was estimated using allometric relationships derived from a destructive sample of trees. The resources available allowed us to sample six trees, which were selected according to their basal caudex diameter. The trees were cut at their bases, sealed in polyethylene bags for transport, and stored at $4{ }^{\circ} \mathrm{C}$ until processing.

Destructive sample: The branches were sawn off at their bases, and the diameter of the bases was measured. The leaves were separated from the branches, counted and weighed. The leaves and the branch wood (including bark) were then oven-dried to constant mass at $65{ }^{\circ} \mathrm{C}$ to determine their dry mass.

To estimate caudex mass, the caudices were sawn into pieces and weighed. The length of the pieces and their diameter at each end was measured, thus allowing the calculation of their volume (formula 1, see below). For dry mass measurement, the pieces were air-dried before drying in an oven to constant mass at $65^{\circ} \mathrm{C}$. For the estimate of caudex age, 31 transverse sections were taken from different individuals in the field, and the number of growth rings was counted under a dissecting microscope.

Non-destructive sample: To estimate the biomass of the stand, 25 randomly selected plots of $2 \mathrm{~m}^{2}$ were investigated. The number of caudices was recorded; their length was measured as well as their basal and apical diameter. The basal diameter of all side branches was measured.

\section{Calculations}

Biomass of Alnus viridis: The number of leaves for each branch was estimated from the regression of branch diameter on numbers of leaves per branch $(\mathrm{y}=27.4 \mathrm{x}-196.8$; $\mathrm{R}^{2}=0.85, P<0.0001, \mathrm{n}=20$; Fig. 1$)$. The leaf fresh mass was obtained by multiplication of the number of leaves with a mean leaf mass $(0.193 \mathrm{~g} / \mathrm{leaf})$, obtained from the measurement of 2000 leaves. The mass of the branch-wood was estimated from the regression of branch diameter on cube root of branch fresh mass $\left(y=1.17 x-5.18 ; R^{2}=0.941\right.$, $P<0.000, \mathrm{n}=25$; Fig. 2). For the estimate of caudex fresh mass, the volume of the caudices was calculated according to formula 1:

$$
V_{\text {trunk }}=\frac{\pi h}{3}\left(r_{1}^{2}+r_{2}^{2}+r_{1} r_{2}\right)
$$

The mass was obtained by multiplication by the factor 0.89 , derived from the caudex pieces of the destructive sample. The dry mass of all fractions was obtained by using conversion factors, derived from oven-dried samples (leaves: 0.52; branch-wood: 0.57, caudices: 0.59 ).

Productivity of Alnus viridis: The regression of branch and caudex age, estimated by counting growth rings, on the branch and caudex diameter $\left(\mathrm{y}=0.5683 \mathrm{x}+6.2951, \mathrm{R}^{2}=\right.$ $0.8728, P<0.000, \mathrm{n}=30$; Fig. 3 ) allowed the calculation of age estimates for all caudices in the non-destructive sample. The mean annual above-ground production of each tree was then calculated as the ratio between its estimated biomass and the age of the caudex. The productivity of the stand was obtained by adding together the annual pro- 


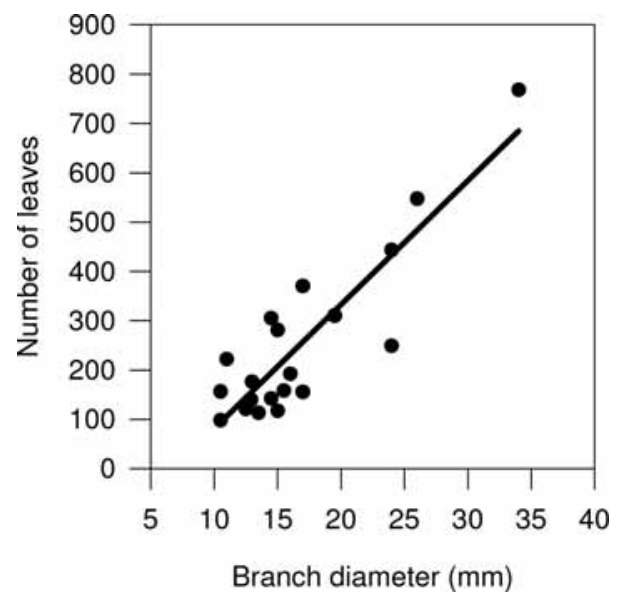

Fig. 1. Relation between number of leaves and branch diameter of Alnus viridis. Linear regression of the number of leaves on the diameter of the branch basis in the destructive sample.

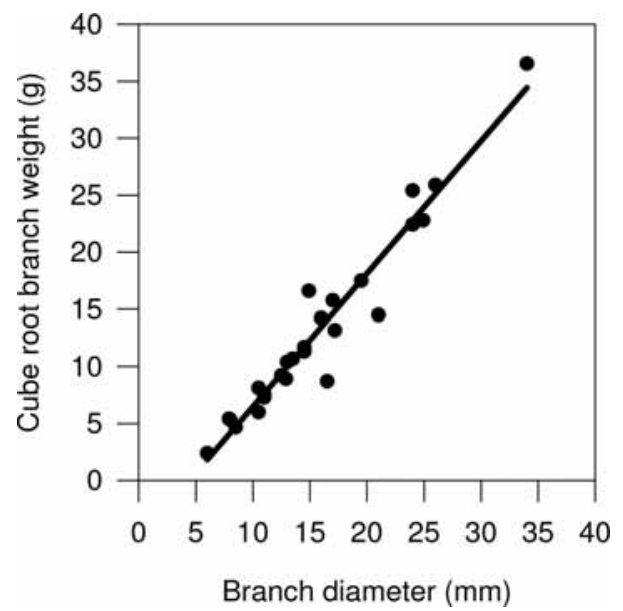

Fig. 2. Relation between branch mass and branch diameter of Alnus viridis. Linear regression of the cube root of branch fresh mass of the destructive sample on the diameter of the branches at their bases.

duction of all trees in the sampled area $\left(50 \mathrm{~m}^{2}\right)$. Leaf production was calculated using dry mass measurements.

Leaf area index ( $L A I)$ : Using the relationship between leaf number per branch and branch diameter established in the destructive sample (Fig. 1), leaf numbers were estimated for all branches and for all trees of the non-destructive sample, respectively. The mean leaf area was determined on 200 randomly selected leaves harvested during the main vegetation season of Alnus viridis, i.e. in July. This yielded the mean leaf area per 


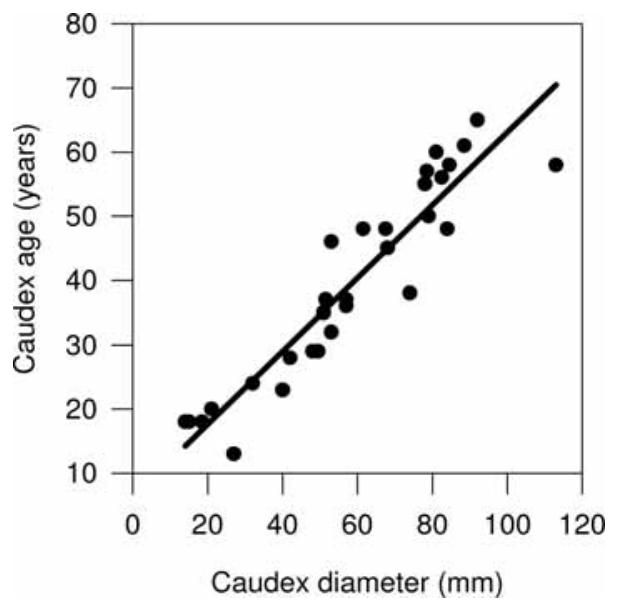

Fig. 3. Relation between age and stem diameter of Alnus viridis. Linear regression of caudex and branch age, estimated by ring counts, on the basal diameter of the caudices and branches.

tree, which was divided by the mean land surface per tree, i.e. the inverse number of caudices per $\mathrm{m}^{2}$, as determined in the non-destructive sample (Grabherr and Schulz 1982).

Species composition and biomass of the herb layer

Four plots of $10 \times 10 \mathrm{~m}^{2}$ were defined in the stand, each containing six randomly selected sub-plots of $2 \times 0.2 \mathrm{~m}^{2}$. The species composition of the 24 subplots was recorded (nomenclature: Binz and Heitz 1986), and the vegetation was harvested. The number of individuals or ramets of each plant species was counted before determining fresh mass and dry mass $\left(65^{\circ} \mathrm{C}\right)$. Since the biomass of the forb layer was determined at the period of maximal development, the productivity was assumed equal to the biomass measured.

\section{Results}

A total of 144 caudices of Alnus viridis were recorded in the $50 \mathrm{~m}^{2}$ of the nondestructive sample ( $0-6.5$ caudices $\mathrm{m}^{-2} ;$ Fig. 4$)$. The calculated density of caudices in the stand was $28800 \mathrm{ha}^{-1}$. The age of the caudices in the non-destructive sample ranged from 13 to 56 years (Fig. 5), with a mean of 34 years. The leaf area index was calculated as 6.08. Estimates of the above-ground biomass of Alnus viridis are given in Table 1.

In the herb layer, 33 species were recorded with 19 small-leaved herbs, seven broadleaved forbs, four ferns and three woody species (Tab. 2). The only tree seedlings found were those of Acer pseudoplatanus. Estimates of the biomass of the herb layer are given in Table 1 . With an above-ground biomass of $1.95 \mathrm{t}$ ha-1, the herb layer contributed only $2.2 \%$ to the total biomass of the Alnetum viridis. Most prominent within this fraction were the broad-leaved forbs with $64.1 \%$ and the ferns with $28.7 \%$ of the biomass of the herb layer. The herbs represented only $4.6 \%$ of the total biomass despite their greater species richness and abundance. 


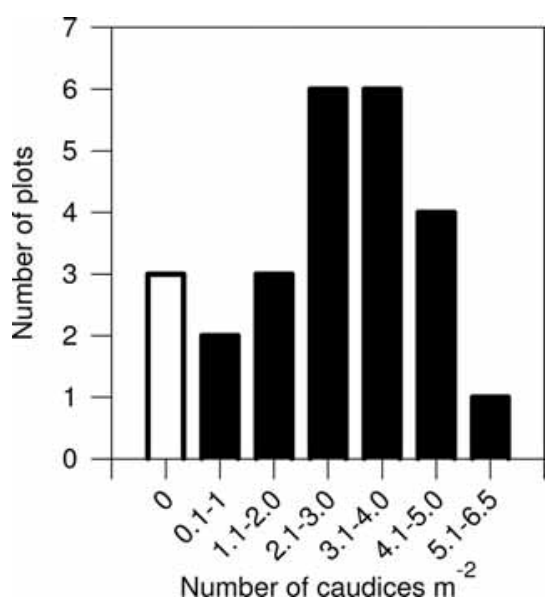

Fig. 4. Density of creeping stems (caudices) within an Alnus viridis stand: frequency distribution of the number of caudices per $\mathrm{m}^{2}$ in 25 sampling plots $\left(2-\mathrm{m}^{2}\right)$.

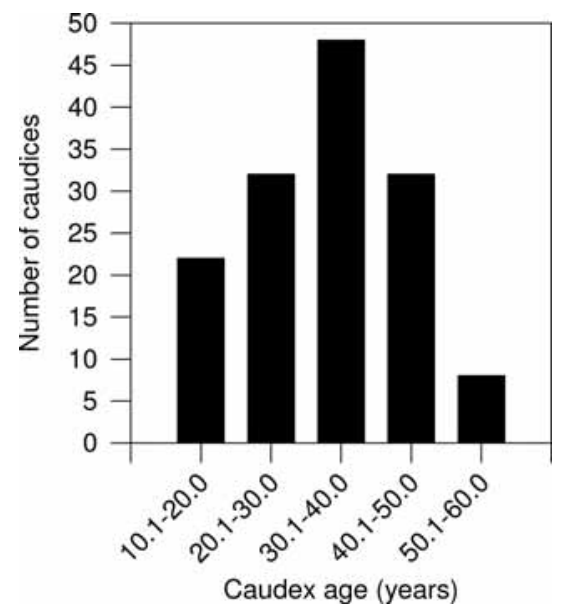

Fig. 5. Age structure of the investigated Alnus viridis stand. The histogram showing the numbers of caudices in different age classes in the non-destructive sample.

The above-ground production of the Alnus viridis stand was estimated to be $8.13 \mathrm{t}$ $\mathrm{ha}^{-1} \mathrm{yr}^{-1}$ (Tab. 3). The annual biomass production was largely dominated by Alnus viridis with a total of $6.18 \mathrm{t} \mathrm{ha}^{-1} \mathrm{yr}^{-1}$. The leaves contributed $61.5 \%$ to the production of Alnus viridis, the growth of the caudices $21.7 \%$ and branch wood $16.8 \%$. The estimated production of caudex and branch wood corresponds to a wood increment of approximately $4.6 \mathrm{~m}^{3} \mathrm{ha}^{-1} \mathrm{yr}^{-1}$. 
Tab. 1. Estimated above-ground biomass (dry mass) of Alnus viridis and of the understorey in a subalpine Alnetum viridis stand.

\begin{tabular}{lcc}
\hline & Biomass t ha $^{-1}$ & \% of total \\
\hline Caudex and bark & 50.2 & 56.2 \\
Branch wood and bark & 33.3 & 37.3 \\
Leaves & 3.8 & 4.3 \\
\hline Total Alnus viridis & 87.3 & 97.8 \\
\hline Forbs & 1.25 & 1.4 \\
Ferns & 0.56 & 0.6 \\
Herbs & 0.09 & 0.1 \\
Woody plants & 0.05 & 0.1 \\
\hline Total herb layer & 1.95 & 2.2 \\
Total Alnetum viridis & 89.25 & 100.0 \\
\hline
\end{tabular}

Tab. 2. Abundance (A) and frequency (F) of plant species in the understorey of the Alnetum viridis. Species are ordered by growth form and by decreasing frequency within growth forms.

\begin{tabular}{|c|c|c|c|c|c|}
\hline & $\mathrm{A}^{\mathrm{a}}$ & $\mathrm{F}^{\mathrm{b}}$ & & $\mathrm{A}^{\mathrm{a}}$ & $\mathrm{F}^{\mathrm{b}}$ \\
\hline Adenostyles alliariae $^{\mathrm{f}}$ & 77.2 & 100.0 & Streptopus amplexifolius $\mathrm{h}$ & 1.0 & 16.7 \\
\hline Peucedanum ostruthium ${ }^{\mathrm{f}}$ & 6.5 & 54.2 & Paris quadrifolia ${ }^{\mathrm{h}}$ & 0.3 & 12.5 \\
\hline Cicerbita alpina $^{\mathrm{f}}$ & 3.5 & 39.6 & Primula elatior ${ }^{\mathrm{h}}$ & 3.4 & 12.5 \\
\hline Ranunculus lanuginosus ${ }^{\mathrm{f}}$ & 1.0 & 20.8 & Deschampsia caespitosa ${ }^{\mathrm{h}}$ & 0.2 & 8.3 \\
\hline Veratrum album ${ }^{\mathrm{f}}$ & 0.4 & 16.7 & Fragaria vesca $^{\mathrm{h}}$ & 0.4 & 8.3 \\
\hline Chaerophyllum villarsii ${ }^{\mathrm{f}}$ & 1.4 & 12.5 & Geum rivale $\mathrm{h}$ & 1.1 & 8.3 \\
\hline Aconitum napellus ${ }^{\mathrm{f}}$ & 1.0 & 10.4 & Homogyne alpina ${ }^{\mathrm{h}}$ & 0.6 & 8.3 \\
\hline Dryopteris carthusiana $^{\mathrm{fe}}$ & 23.9 & 83.3 & Agrostis agrostiflora $^{\mathrm{h}}$ & 0.3 & 4.2 \\
\hline Athyrium distentifolium $^{\mathrm{fe}}$ & 13.3 & 41.7 & Alchemilla xanthochlora $\mathrm{h}$ & 0.4 & 4.2 \\
\hline Phegopteris connectilis ${ }^{\mathrm{fe}}$ & 2.9 & 18.8 & Geranium silvaticum $^{\mathrm{h}}$ & 0.1 & 4.2 \\
\hline Asplenium viride $\mathrm{fe}^{\mathrm{fe}}$ & 0.4 & 8.3 & Hieracium silvaticum $^{\mathrm{h}}$ & 0.1 & 4.2 \\
\hline Viola biflora ${ }^{\mathrm{h}}$ & 84.2 & 87.5 & Ranunculus grenierianus $^{\mathrm{h}}$ & 0.3 & 4.2 \\
\hline Oxalis acetosella ${ }^{\mathrm{h}}$ & 173.2 & 62.5 & Veronica latifolia $^{\mathrm{h}}$ & 0.1 & 4.2 \\
\hline Saxifraga rotundifolia ${ }^{\mathrm{h}}$ & 115.3 & 45.8 & Rubus saxatilis ${ }^{\mathrm{w}}$ & 3.9 & 47.9 \\
\hline Soldanella alpina ${ }^{\mathrm{h}}$ & 14.4 & 29.2 & Vaccinium myrtillus ${ }^{\mathrm{w}}$ & 8.9 & 33.3 \\
\hline Stellaria nemorum s.1. ${ }^{\mathrm{h}}$ & 19.4 & 29.2 & Acer pseudoplatanus ${ }^{\mathrm{w}}$ & 0.5 & 8.3 \\
\hline Solidago virgaurea ${ }^{\mathrm{h}}$ & 2.0 & 22.9 & & & \\
\hline
\end{tabular}

${ }^{a}$ Mean number of individuals or ramets per square meter.

${ }^{b}$ Weighted mean of percentage of sub-plots $(n=24)$.

${ }^{\mathrm{f}}$ forbs, ${ }^{\text {fe }}$ ferns, ${ }^{\mathrm{h}}$ small-leaved herbs and grasses, ${ }^{\mathrm{w}}$ woody plants.

\section{Discussion}

Within the Alnetum viridis, three vegetation layers can be distinguished. The ground flora, approximately $20 \mathrm{~cm}$ in height, shows a high diversity of small-leaved herbs and grasses (Tab. 2), as well as mosses (Mürner 1998). Despite the high abun- 
Tab. 3. Estimated above-ground biomass production of Alnus viridis and of the understorey in a subalpine Alnetum viridis stand (dry mass).

\begin{tabular}{lcc}
\hline & Biomass t ha $^{-1}$ & \% of total \\
\hline Caudex and bark & 1.34 & 16.5 \\
Branch wood and bark & 1.04 & 12.8 \\
Leaves & 3.80 & 46.7 \\
\hline Total Alnus viridis & 6.18 & 76.0 \\
\hline Forbs & 1.25 & 15.4 \\
Ferns & 0.56 & 6.9 \\
Herbs & 0.09 & 1.1 \\
Woody plants & 0.05 & 0.6 \\
\hline Total herb layer & 1.95 & 24.0 \\
Total Alnetum viridis & 8.13 & 100.0 \\
\hline
\end{tabular}

dance of these plants, they do not contribute significantly to the biomass of the Alnetum. The only seedlings of forest trees occurring sporadically are those of Acer pseudoplatanus L. The lack of Alnus viridis seedlings suggests that light conditions may be inadequate in older stands, due to the ground flora and the LAI of 6.1, and that regeneration in established stands occurs mainly through adventive shoots (i.e. clonal growth).

The upper layer of the ground flora consists of a few species of broad-leaved forbs and ferns, the forbs being the main component of the understorey biomass. Despite the high and dense growth of the understorey vegetation, the above-ground production of $195 \mathrm{~g} \mathrm{~m}^{-2} \mathrm{yr}^{-1}$ is less than that observed in rich subalpine meadows dominated by Carex ferruginea Scop. or Carex sempervirens Vill. with an above-ground dry matter production of $375 \mathrm{~g} \mathrm{~m}^{-2} \mathrm{yr}^{-1}$ and $550 \mathrm{~g} \mathrm{~m}^{-2} \mathrm{yr}^{-1}$, respectively (Gökçeoglu and Rehder 1977).

The biomass recorded for Alnus viridis in the present study is similar to the values obtained by Richard (1969) and Rubli (1976), though the leaf area index was estimated to be 1.2 times higher than the maximal value reported by Rubli (1976; Tab. 4).

Körner and Hilscher (1978) observed a considerably higher radial growth of the caudices of $A$. viridis compared to other tree species near the timberline. Indeed, both productivity and biomass of Alnus viridis are high, compared to shrub communities from the subarctic or subalpine zone (Tab. 5). Even plant associations dominated by dendroid species, such as Picea abies and Betula pubescens s.l., have a lower productivity and biomass. The high growth performance of $A$. viridis is certainly influenced by the high caudex density, resulting from the clonal growth and probably the better $\mathrm{N}$ availability due to the root symbiosis with nitrogen-fixing Frankia bacteria.

Another distinctive feature of $A$. viridis is the high ratio of annual production observed in comparison with total biomass (Tab. 5). The development of extra foliage, resulting in the high leaf area index observed, is the main component of the annual productivity. This highlights a feature of deciduous woody vegetation near its climatic lim- 
Tab. 4. Comparison of the biomass (dry mass) and leaf area index obtained in three studies of subalpine Alnetum viridis stands.

\begin{tabular}{llll}
\hline $\begin{array}{l}\text { Alnus viridis leaves } \\
\left(\mathrm{t} \mathrm{ha}^{-1}\right)\end{array}$ & $\begin{array}{l}\text { Understorey (forbs) } \\
\left(\mathrm{t} \mathrm{ha}^{-1}\right)\end{array}$ & $\begin{array}{l}\text { Alnus viridis } \\
\text { leaf area index }\end{array}$ & References \\
\hline $5.2-9.1 *(10.0-17.5)$ & - & - & Richard 1968 \\
$0.9-2.3$ & $1.00-3.35$ & $0.86-5.04 * *$ & Rubli 1976 \\
3.8 & 1.25 & 6.08 & Present study \\
\hline
\end{tabular}

* Dry mass was calculated with the conversion factor of the present study. Fresh mass values reported by Richard (1968) are given in parentheses.

** Data from four differently dense stands.

Tab. 5. Above-ground productivity estimates of woody species in plant associations of cooler climates with a vegetation structure similar to that of subalpine Alnetum viridis stands.

\begin{tabular}{lllll}
\hline & $\begin{array}{l}\text { Biomass } \\
\mathrm{t} \mathrm{ha}^{-1}\end{array}$ & $\begin{array}{l}\text { Production } \\
\mathrm{t} \mathrm{ha}^{-1} \text { year }^{-1}\end{array}$ & Turnover* & Reference \\
\hline Salix glauca/S. lanata & c. 5.3 & c. 0.9 & 0.17 & Sampson and Jones 1977 \\
Salix glauca & 18.4 & $1.3-1.6$ & 0.08 & Sampson and Jones 1977 \\
Betula pubescens & 54.9 & 2.1 & 0.04 & Elkington and Jones 1974 \\
Picea abies/Betula sp. & 68.6 & 2.8 & 0.04 & Sampson and Jones 1977 \\
Alnus viridis & 87.3 & 6.2 & 0.07 & Present study \\
\hline
\end{tabular}

* Annual production divided by biomass

its: the plants lose a lot of material annually, mainly as shed leaves but also as damaged twigs and caudices (Sampson and Jones 1977).

It can be concluded that the Alnetum viridis is one of the most productive plant associations at higher altitudes. The high productivity, along with the clonal reproduction strategy, of $A$. viridis are fundamental properties required for the rapid spread of this vegetation type observed throughout the subalpine zone in Switzerland with changing agricultural practice.

\section{Résumé}

La biomasse d'une Aunaie verte (Alnetum viridis) a été mesurée dans un site de composition typique de la zone subalpine de Suisse et la productivité primaire de cette association a été estimée. Une biomasse de $89.3 \mathrm{t} \mathrm{ha}^{-1}$ a été enregistré, à laquelle l'aune vert contribue à $97.8 \%$ et la végétation herbacée à $2.2 \%$. La productivité annuelle de l'aune vert est estimée à $6.18 \mathrm{t} \mathrm{ha}^{-1} \mathrm{a}^{-1}$, dont $61.5 \%$ sont dus à la production des feuilles, $21.7 \%$ à la croissance des troncs et $16.8 \%$ à la croissance des branches. La biomasse et la production primaire de l'Aunaie verte est élevée en comparaison à d'autres associations boisées des zones subarctiques et subalpines. Ceci pourrait être dû à la grande densité des troncs, qui est interprétée comme étant l'effet d'une croissance clonale. 
We thank Ernst Bhend, Suzanne Dreier, Nicolas Küffer, Rolf Mürner, Flor Oberli, and Sascha Wettstein for their assistance in fieldwork.

\section{References}

Anthelme F., Cornillon L. and Brun J.J. 2002. Secondary succession of Alnus viridis (Chaix) DC. in Vanoise National Park, France: Coexistence of sexual and vegetative strategies. Ann. For. Sci. 59: 419-428.

Anthleme F., Michalet R., Barbaro L. and Brun J.J. 2003. Environmental and spatial influences of shrub cover (Alnus viridis DC.) on vegetation diversity at the upper treeline in the inner western Alps. Arc. Antarc. Alp. Res. 35: 48-55.

Barbero M., Cadel G., Gensac P., Ozenda P. et Richard J.-L. 1991. Carte de la Végétation des Alpes. Tignes-Larches $n^{0}$ 55-61. C.N.R.S. Toulouse.

Binz A. und Heitz Ch. 1986. Schul- und Exkursionsflora für die Schweiz. Schwabe \& Co, Basel.

Brassel P. und Brändli U. 1999. Schweizerisches Forstinventar. Ergebnisse der Zweitaufnahme 1993-1995. Birmensdorf, Eidgenössische Forschungsanstalt für Wald, Schnee und Landschaft. Bern, Bundesamt für Umwelt, Wald und Landschaft. Haupt, Bern.

Elkington T.T. and Jones B.M.G. 1974. Biomass and primary productivity of birch (Betula pubescens s. lat.) in South-West Greenland. J. Ecol. 62: 821-830.

Gökçeoglu M. and Rehder H. 1977. Nutrient turnover studies in Alpine ecosystems III Communities of lower altitudes dominated by Carex sempervirens Vill. and Carex ferruginea Scop. Oecologia 28: 317-331.

Grabherr G. und Schulz L. 1982. Bestimmung der pflanzlichen Biomasse und Produktion mit der Erntemethode und Bestimmung des Blattflächenindex. In: Janetschek H. (ed.) Ökologische Feldmethoden. Ulmer, Stuttgart, p. 62-72.

Graf Ch., Böll A. und Graf F. 2003. Pflanzen im Einsatz gegen Erosion und oberflächennahe Rutschungen. Merkbl. Prax. 37, Eidgenöss. Forsch.anst. WSL, Birmensdorf.

Körner Ch. und Hilscher H. 1978. Wachstumsdynamik von Grünerlen auf ehemaligen Almflächen an der zentralalpinen Waldgrenze. In: Cernusca A. (ed.) Ökologische Analysen von Almflächen im Gasteiner Tal. Veröffentlichungen des Österreichischen MaB Hochgebirgsprogramms Hohe Tauern, Band 2. Universitätsverlag Wagner, Innsbruck, p. 187-193.

Mürner R. 1998. Grünerlengebüsche der Innerschweiz - Untersuchungen zur Vegetation. Ökologie und Dynamik, mit besonderer Berücksichtigung der Moose und Pilze. MSc. thesis, University of Bern, Switzerland.

Richard L. 1967. L'aire de répartition de l'Aune vert, Doc. Carte Végét. des Alpes V: 81-113.

Richard L. 1968. Ecologie de l'Aune vert, Doc. Carte Végét. des Alpes VI: 107-157.

Richard L. 1969. Une interprétation eco-physiologique de la répartition de l'Aune Vert (Alnus viridis), Doc. Carte Végét. des Alpes VII:7-23.

Rubli D. 1976. Waldbauliche Untersuchungen in Grünerlenbeständen. Beih. Z. Schweiz. Forstvereins 56.

Sampson E.J. and Jones B.M.G. 1977. The productivity of Salix glauca L. in Arctic Norway. Ann. Bot. 41: 155-161.

Wettstein S. 1999. Grünerlengebüsche in den Schweizer Alpen - Ein Simulationsmodell aufgrund abiotischer Faktoren und Untersuchungen über morphologische und strukturelle Variabilität. MSc. thesis, University of Bern, Switzerland, 1999.

Wettstein S. 2001. Der Einfluss abiotischer Faktoren auf die Morphologie der Grünerle. Bot. Helv. 111: 31-44. 